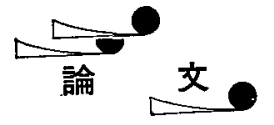

\title{
赤外線映像装置を利用した構造物壁面より漏洩する 流体の漏出箇所の検出に関する研究*
}

\author{
稲垣照美**，中村弘史***，岡本芳三**
}

\section{Detection of a Leak on a Surface of the Structure using Infrared Radiometer}

\author{
Terumi Inagaki, Hiroshi Nakamura and Yoshizo OKamoto
}

\begin{abstract}
In the constructional fields, the detection of a leak on a surface is important to maintain and manage various structures such as bank, dam, tunnel and so on. When fluid is leaking out a surface of the structure, its temperature is not generally consistent with the environmental temperature. Furthemore, expansion flow of high-pressure gas jetted from a nozzle lessens its temperature and cools a surface around a nozzle. With the aid of infrared thermograph, we can detect the leak point where the temperature difference between the solid surface and the leaking fluid is remarkable. In this paper, the availability of the infrared radiometer was experimentally studied to establish a more effective detection method of leak.
\end{abstract}

Key words : Thermal Visualization, Infrared Radiometer, Leak, Detection Method, Remote Sensing, Non Destructive Testing

\section{1. 緒論}

建設分野に打ける提防，ダム，トンネルおよび 水路等の水利構造物からの涌水括よび漏 水箇所 や，機械分野に括ける配管，容器，率熱層等の機 器構造物からの水, 空気, ガス等の漏洩簀所を検 出し, その漏洩量を求めることが構造物の維持・ 管理を行う上で重要になる。特に地下トンネルな ぞで発生する漏洩箇所の早期診断は，交通・輸送 手段の安全性を確保する上でも極めて重要な事柄 である。

*原稿受付 1994年 4 月20日

**正会員 茨城大学工学部

***茨城大学大学院
一般に流体が容器や流路等の壁面やその継ぎ目 を通して外側に湧出あるいは漏洩する場合, 漏洩 流体の温度は外気に接した壁面の表面温度とは一 致していないことが多い。また，気体が高圧で噴 出する場合には，気体の膨張によりその温度は低 下し，噴出孔周辺の壁面温度を低下させる。した がって，漏出箇所周辺の温度場を観察することに より，その画像から壁面との温度差の大きい箇所 にひび割れなどの漏出簓所を検出することが可能 となる。

本研究では，これらの涌出筒所の検出に赤外線 映像装置を適用することで，本手法の有効性を検 証するとともに, 漏洩流量の検出やその伝熱機構 について併せて検討することにてた ${ }^{1) 39}$ 。赤外線 
映像装置は，物体表面から放射される赤外線エネ ルギーを遠隔非接触で捕らえ，2次元の放射温度 画像として表示することを特色としている。その ため本手法は，機器や構造物を広範困に計測・診 断するための有効な手段と考学られる。

\section{2. 実験装置と可視化法}

実験装置の基本構成をFig. 1 (a)抢よび(b)に示 す。周辺からの反射の影響を防止するため，赤外 線カメラと試験体は断熱材で覆われた暗室空間の 中に入れ, 温度調節器と熱交換器により暗室空間 内部の空気と試験体の温度が一定に保たれるよら に制御した。また, 試験体のモデル形状を Fig. 2 に示寸。試験体忹, 縦 $300 \mathrm{~mm}$, 横 $180 \mathrm{~mm}$, 厚 さ $50 \mathrm{~mm}$ のモルタル製基板で構成され，コンク リートと砂の混合比は 7:3である。実験は, 試 験体内部に断熱材で覆われた内径 $1.0 \mathrm{~mm}$ の漏 洩用パイプを埋め达み，そこから流体を漏洩させ て実施した。漏洩孔は，試験体下端から $240 \mathrm{~mm}$ の位置に設定してある。漏洩水は，試験体上方に 設置した水槽から自由落下させ，流量計扣よび流

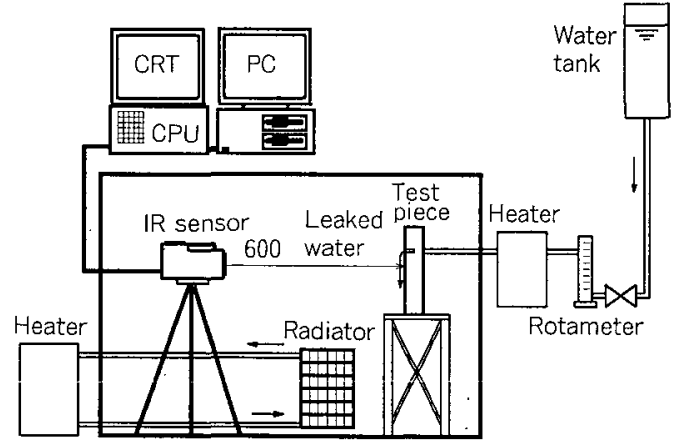

(a) Experimental apparatus for vertical surface

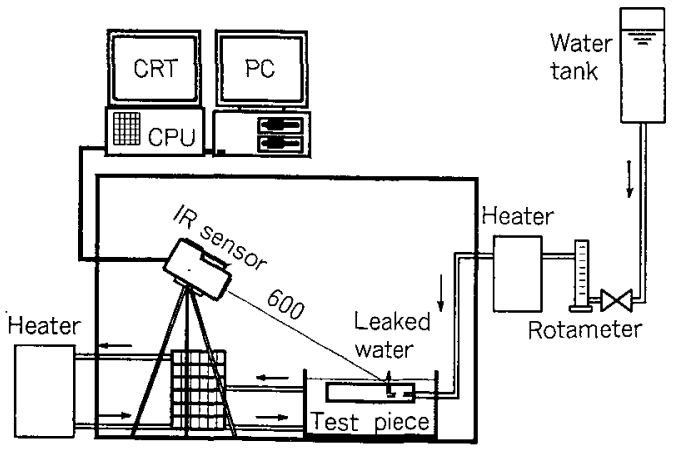

(b) Experimental apparatus for horizontal surface

Fig. 1 Experimental apparatus

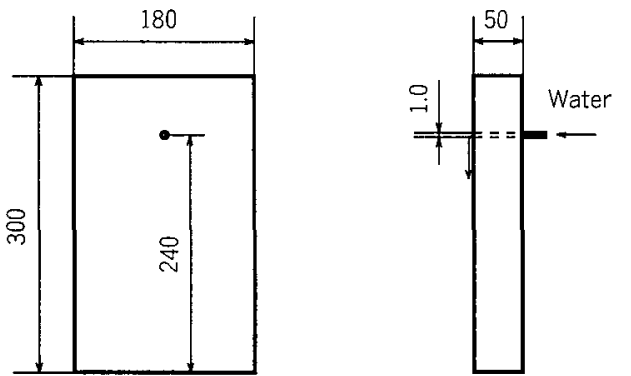

Fig. 2 Test piece

量制御弁により漏出量を制御・計測した。本研究 では，まず第一に垂直面と水平面について，それぞ れ温度と流量の組合わせを変えたもデル実験をい くつか行い，漏洩箇所検知に関する基礎的な考察 を加えることにした。垂直面の実験では，実際の 状沉を反映させるため，試験体表面全体を水で濡 らした状態で実験を行った。るた，水平面の実験 では，試験体全体を水槽の中沈沈め，水位を試験 体の上方より $5 ， 10 ， 15 ，$ および $20 \mathrm{~mm}$ の位置 に取り，水槽内部の水と試験体の温度を一定にし た。本実験は，トンネル底面など，水面下から地 下水が湧水する状況を想定したモデルによる基礎 実験である。

つぎに実際の亀裂面への応用として，任意形状 の亀裂より涌水している試験体表面を可視化し， 本検出法の有効性を検証した。さらに地層面から の漏洩籄所の検知への応用として，土中から漏洩 水が湧き出す場合の実験を実施した。

実験恃垂直・水平面のいずれの場合も表面温度 を一定にした後，湧水面の温度の経時変化を赤外 線映像装置で可視化し，その映像をコンピュータ 一に記録した。漏洩水の温度和よびその周囲の温 度は，放射温度画像㘧よび CA 熱電対を用いて 測定した。水は赤外線を表面で吸収するために黒 体と考光てょく，水の放射温度は泳济実際の温度 と考えて差し支充ない。したがって，水で需らし たコンクリート表面の放射温度は実際の温度と考 克てょい。本研究では，奏際の表面温度に基づい て放射温度の検定を行い，真の温度を同定してい る。

\section{3. 可視化結果および考察}

\section{1 垂直面における漏洩モデル実験}


Fig. 3 (a)扣よび(b)は, 赤外線映像装置で可 視 化した垂直面上の涌水の放射温度画像をとれぞれ 示したものであり, 涌水開始 3 分後の 結 果であ る。壁面および漏洩水の温度は，それぞれ(a)は30 ${ }^{\circ} \mathrm{C}$ および $20^{\circ} \mathrm{C}$, (b)は $35^{\circ} \mathrm{C}$ および $20^{\circ} \mathrm{C}$ である。 また漏洩流量は, 上から順に 10,20 拈よび $30 \mathrm{~cm}^{3} /$ min である。漏洩水は垂直に下降し, 流れに沿

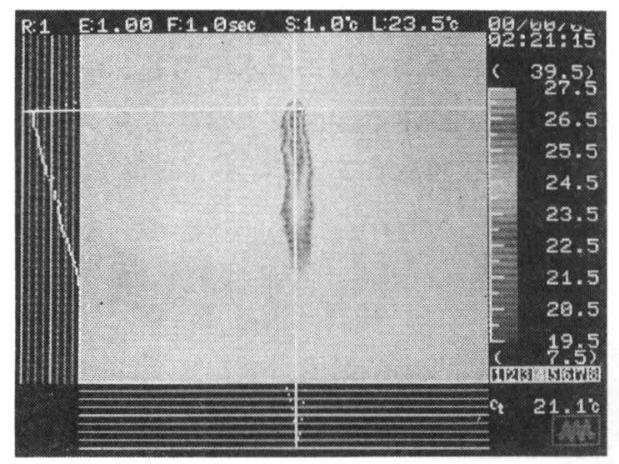

$10 \mathrm{~cm}^{3} / \mathrm{min}$

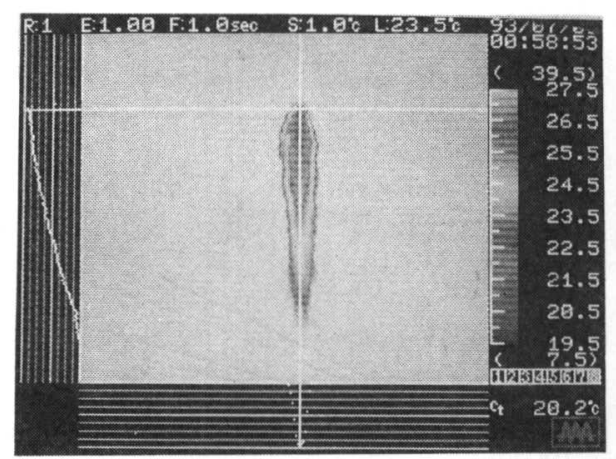

$20 \mathrm{~cm}^{3} / \mathrm{min}$

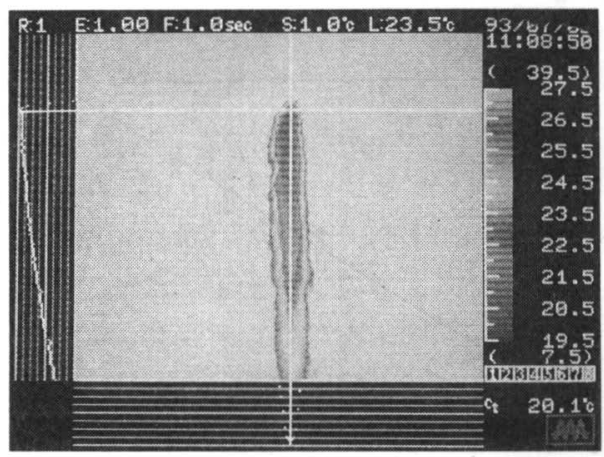

$30 \mathrm{~cm}^{3} / \mathrm{min}$

(a) Wall temp. $30^{\circ} \mathrm{C}$, Water temp. $20^{\circ} \mathrm{C}$
ってその幅を広げながら落下して行く様子がわか る。写真中の左側と下側のグラフは, 画面十字線 上の温度分布を示している。壁面より温度の低い 漏洩水は壁面から熱を得ることにより, その温度 は漏洩箇所からの距離が大きくなるほど上昇し, 壁面の温度に近づいていくことがわかる。また， これらの写真を比較することにより, 漏洩水温と

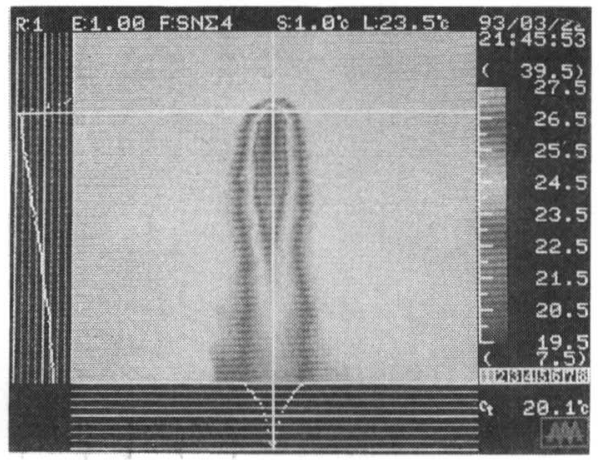

$10 \mathrm{~cm}^{3} / \mathrm{min}$

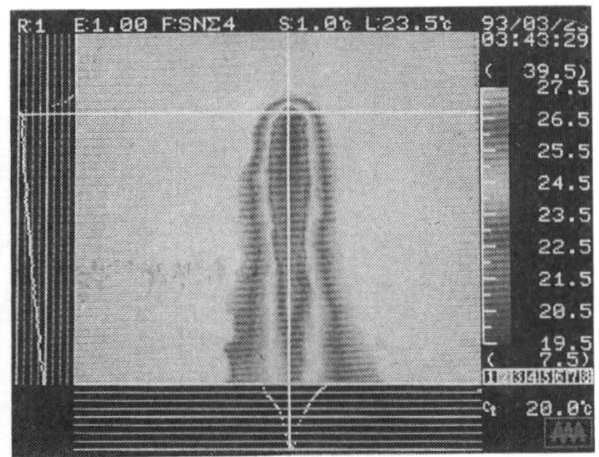

$20 \mathrm{~cm}^{3} / \mathrm{min}$

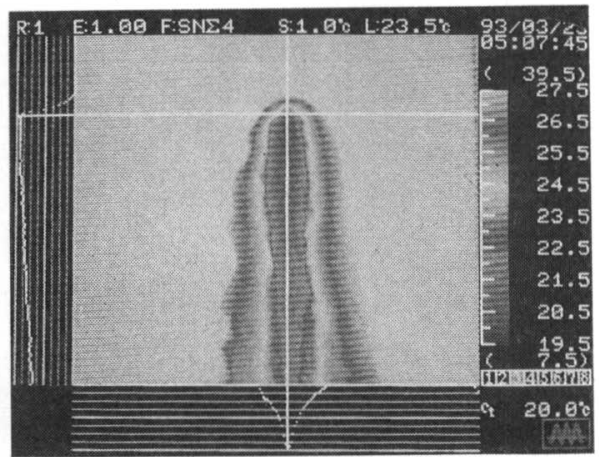

$30 \mathrm{~cm}^{3} / \mathrm{min}$

(b) Wall temp. $35^{\circ} \mathrm{C}$, Water temp. $20^{\circ} \mathrm{C}$

Fig. 3 Thermograph on a vertical surface 
壁温との温度差が大きいほど，また漏洩流量が少 ないほど，漏波水温は壁面温度に早く漸近するこ とがわかる。

Fig. 4 (a)，(b)和よび(c)は，綎軸に無次元 温度 $\theta=\left(T_{X}-T_{0}\right) /\left(T_{W}-T_{0}\right)$ を, 横軸に漏洩孔から の距離 $x \mathrm{~mm}$ を取って上記実験結果を整理した ものである。(a)，(b)执よび(c)は，壁面扣よび漏洩 水の温度が，それぞれ $20^{\circ} \mathrm{C}$ と $15^{\circ} \mathrm{C}, 30^{\circ} \mathrm{C}$ と 20 ${ }^{\circ} \mathrm{C}$ および $35^{\circ} \mathrm{C}$ と $20^{\circ} \mathrm{C}$ の場合である。また図の 中の記号口○ $\Delta$ は，漏洩流量がそれぞれ $10 ， 20$ 和 よび $30 \mathrm{~cm}^{3} / \mathrm{min}$ の場合を示している。一連の図

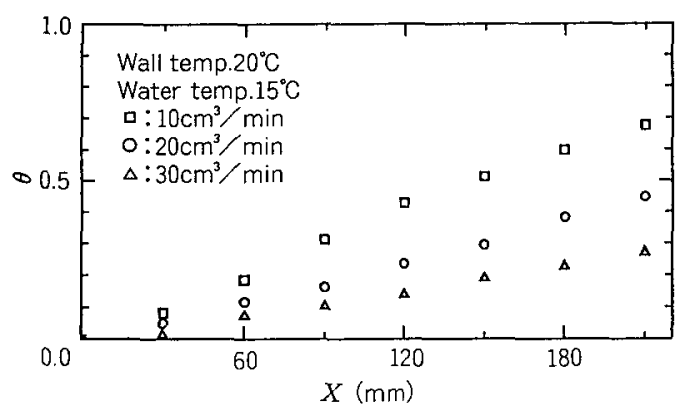

(a) Wall temp. $20^{\circ} \mathrm{C}$, water temp. $15^{\circ} \mathrm{C}, 10 \mathrm{~cm}^{3} / \mathrm{min}$

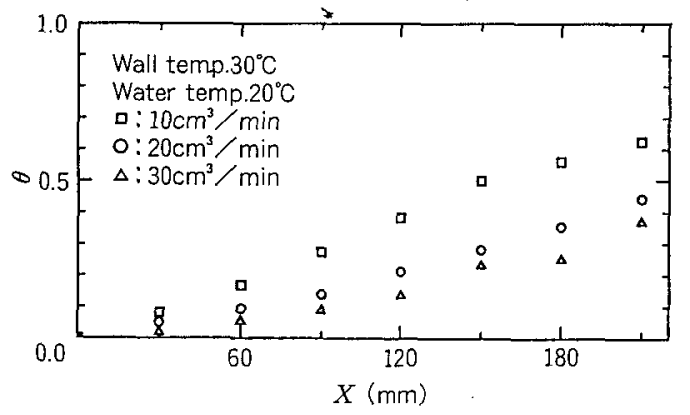

(b) Wall temp. $30^{\circ} \mathrm{C}$, water ternp. $20^{\circ} \mathrm{C}, 20 \mathrm{~cm}^{\mathrm{s}} / \mathrm{min}$

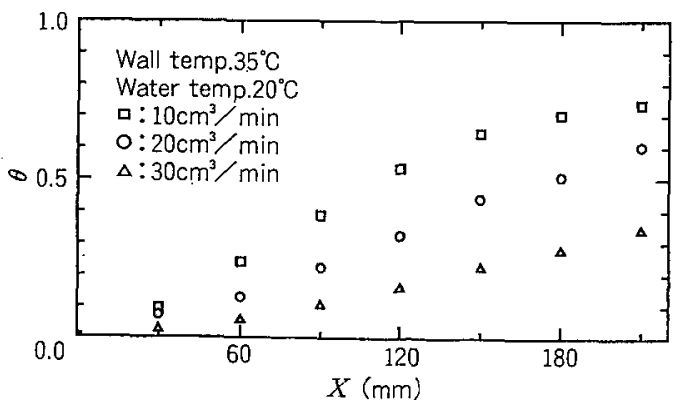

(c) Wall temp. $35^{\circ} \mathrm{C}$, water temp. $20^{\circ} \mathrm{C}, 30 \mathrm{~cm}^{3} / \mathrm{min}$

Fig. 4 Non-dimensional temperature along a vertical surface
から, 無次元温度分布 $\theta(x)$ は，流量が小さくな るとともに増加する傾向にあると言える。

Fig.5は，Fig. 4 の結果を漏洩流量が10，20 および $30 \mathrm{~cm}^{3} / \min$ それぞれ場合について一つ の図にまとめたものである。ハッチングされた部 分は，一連の実験の標準偏差を考慮した範囲を示 す。 $\theta$ による無次元整理から，漏洩流量が温度分 布に対する主要なパラメータとなっていることが わかる。な推面と漏洩水との温度差が $2^{\circ} \mathrm{C}$ 以 下の場合，漏洩筒所の特定が困難であった。この 埸合，漏洩䇢所周辺に温水や冷水をかけて一時的 に壁面と漏洩水との温度差を大きくし，温度場の 経時変化を可視化することにより，漏洩筒所を検 知することが可能となる。

Fig. 6 は，より一般化を図るため，無次元温 度 $\theta$ を縱軸に，無次元距離 $\zeta=(X / L) R e$ を横軸 にとって漏洩水の温度分布を整理し直したもので ある。屯た図中の直線は最小二乗法によって求め たものであり， $\theta=8.3 \times 10^{-5} \cdot \zeta^{1.2}$ で表わされる。 应から明らかなよらに，無次元整理を行うこと で，実験諸条件に関係なく温度分布を整理できる

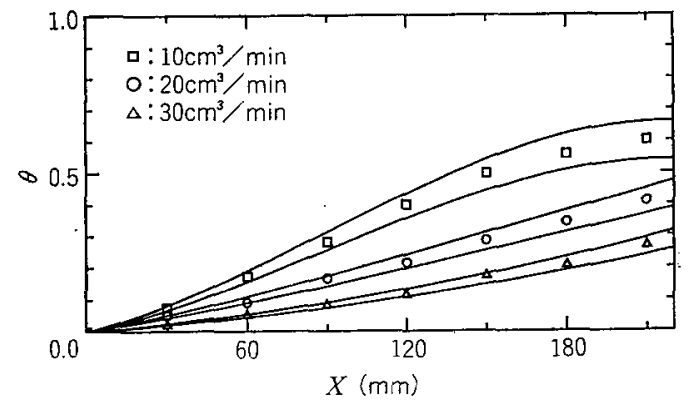

Fig. 5 Non-dimensional temperature along a vertical surface

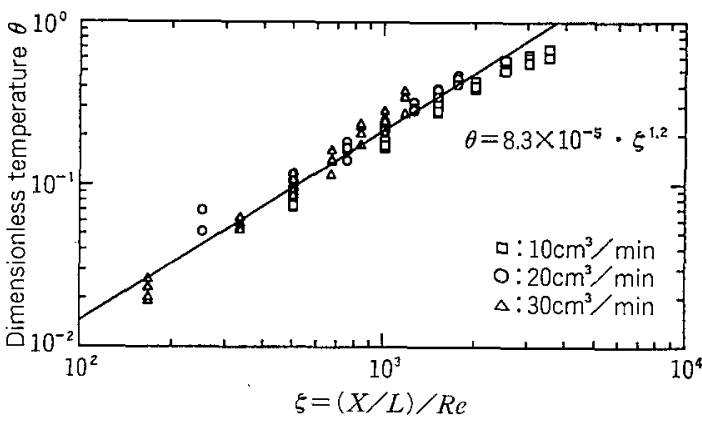

Fig. 6 Non-dimensional temperature along a vertical surface 
ことが明らかになった。

つぎに Fig. 7 は, 漏洩水の伝熱機構を調べるた め, $N u=\left[\left\{\rho C_{p}\left(T_{W}-T_{0}\right) / A\left(T_{X}-T_{0}\right)\right\} \cdot L\right] / \lambda て ゙$ 定義される無次元数を縦軸にとり，無次元距離 $\zeta$ を横軸にとったものである。ただし，ここで求め た無次元数は，流水方向の温度上昇が壁面からの 熱移動のみによるものといら仮定の下に求めたも のである。図中の直線は，最小二乗法によっても とめたものであり， $N u=4.0 \times 10^{4} \cdot \zeta^{-1.2}$ で表現 することができる。図より，漏洩流量が多い烓ど あるいは漏洩箇所に近い上流汪ど無次元数が 1 よ り大きく，熱移動は対流熱伝達による支配が強い ことがわかる。しかしながら下流に行くはど流れ が広範囲に拡散するため, 対流熱輸送量が減少し, 伀導による熱輸送支配が強まると考えられる。こ のことは, 無次元数が下流漂ど小さくなることか らも確認できる。

\section{2 水平面における漏洩モデル実験}

Fig. $8(\mathrm{a})$ 和よび(b)は，漏洩試験体を水平に打 き, 水面下 $5 \mathrm{~mm}$ の水槽の中に沈めた状態で漏洩 孔より水を涌き出させ，漏洩筒所和よび一連の涌 水の広がりの様子を可視化したものである。壁面 温度, 漏洩水温执よび漏洩水量は, (a)は $18^{\circ} \mathrm{C}$, $10^{\circ} \mathrm{C}$ 扰よび $30 \mathrm{~cm}^{3} / \mathrm{min}$ で,上から順に実験開始 から 5,30 执よび 180 秒後，(b)は $30^{\circ} \mathrm{C}, 25^{\circ} \mathrm{C}$ およ び $10 \mathrm{~cm}^{3} / \mathrm{min}$ で, 上から順に 5,20 叔よび 120 秒後の写真である。漏洩孔は水面下にあるため直 接肉眼では観察できないが，赤外線映像装置を利 用することにより，周囲との温度美からその位置 を明確に検知することができる。涌き出した冷水 は約 5 秒後に低温点として現われ，その後 2 方向

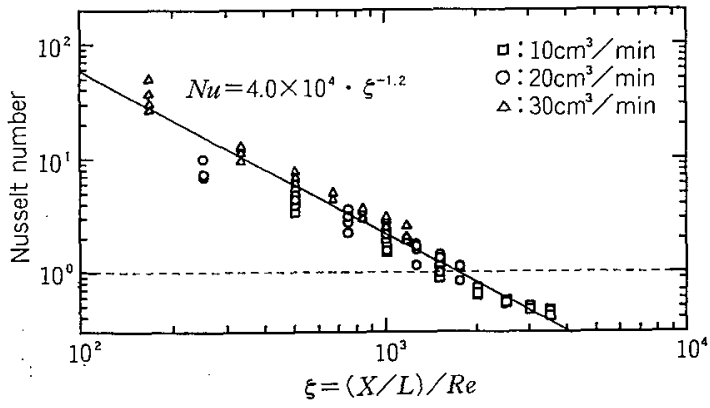

Fig. 7 Non-dimensional heat transfer rate along a vertical surface
に分皮して広がっていく。この現象は流量が多い ほど，水面の高さが高いほど顕著に現われるが， 分岐する方向は一定しない。特に水面の高さが 15 $\mathrm{mm}$ 以上で流量が $30 \mathrm{~cm}^{3} / \mathrm{min}$ の場合, 数秒ご とに分肢する方向が変化するのが観察された。漏 洩水が 2 方向に分岐するのは，試験体の形状によ るものではなく，水の表面張力方るいは水面のわ ずかな擾乱によるものと考觉られる。

\section{3 実際の亀裂面への応用}

以上，一連の基憷的実験では，モデル化された 漏洩孔に対する漏洩简所の検出に関する検討を行 心，赤外線胦像装置利用の適用性・有效性を検 証することができた。したがって，本節ではより 実際の漏油形態に近い試験体を検出対象とし，本 検出法の応用例を具体的に考光てみることにし た。

Fig. 9 は，本実験で使用した試験体を示す。 これは, 縦 $250 \mathrm{~mm}$, 横 $250 \mathrm{~mm}$, 厚さ $50 \mathrm{~mm}$ の 市販コンクリートブロックを二つに割り, 再度接 着したるのである。ここでは，亀裂形態の異なる 試験体を2 個制作し，それぞれを試験体 $\mathrm{A}$ ，試験 体 Bとして使用した。試験体の側面および裹面に は，防水塗料を塗布し，表面からのみ漏洩するよ らにした。Fig. 10 (a)特よび Fig. 11 (a)は，試 験体 $\mathrm{A}$ 扣よび $\mathrm{B}$ 表面を赤外線映像装置で可視化 した放射温度画像であり，Fig.10 特よびFig. 11 の(b)はこれらの画像に扣ける温度の測定感度と範 囲を変化させたものである。まず試験体Aに関す 万 Fig. 10(a)の画像から，3 所の漏洩筋が見ら れ，この部分から漏洩していることが分かる。し かし，(b)の上らに温度の測定感度と測定範团を変 更することで，最初1か所からの漏洩と思われた 最右翼の漏洩筋が，実際は上部漏洩籄所からの漏 洩筋の中にさらに一つの漏洩策所が隠れて扣り， 漏洩孔が二つあることが確認できる。ここで，画 像中の英小文字は, 温度の測定範囲を少しずつ变 化させていくことで確認された低温点（漏れ筒 所）の位置と，その順番を表わしている。その結 果, 最終的に漏洩簓所は $\mathrm{a} \sim \mathrm{g}$ の 7 か所が特定で き，さらに低温部分の広がり方からc〜d間に微 少な漏れが生じていることが予想でさる。同様に して, 試験体Bについても 7 か所の漏洩籄所が特 


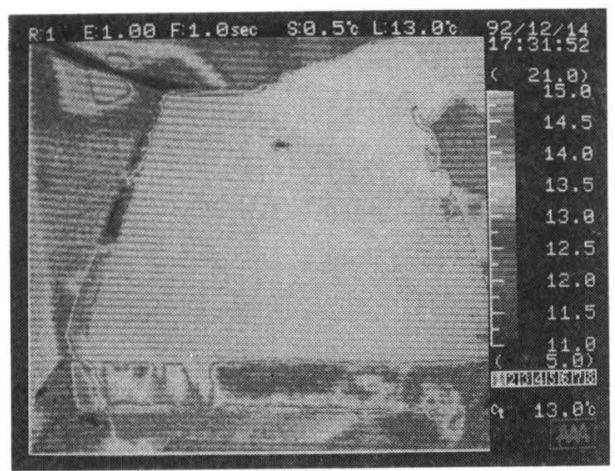

After 5 second

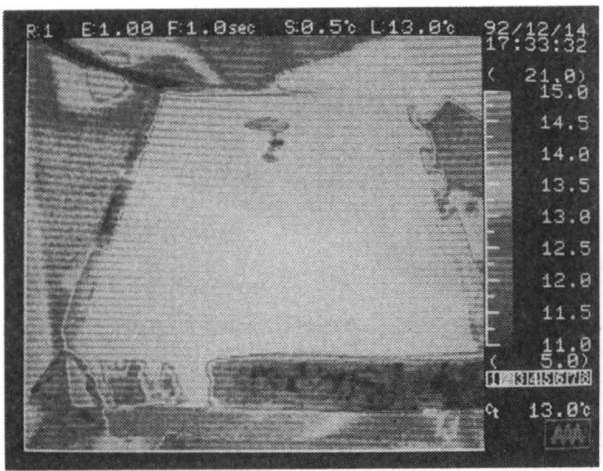

After 30 second

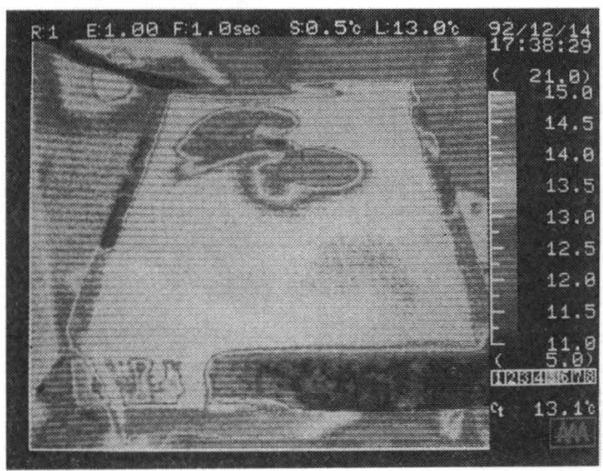

After 180 second

(a) $30 \mathrm{~cm}^{3} / \mathrm{min}$, Wall temp. $18^{\circ} \mathrm{C}$, Water temp. $10^{\circ} \mathrm{C}$

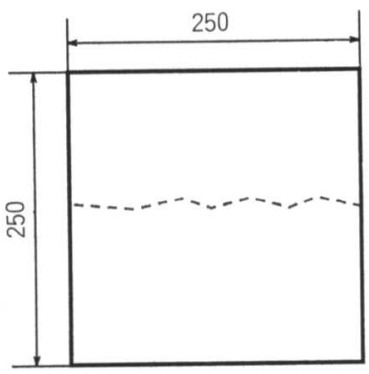

Fig. 8 Thermograph on a horizontal surface

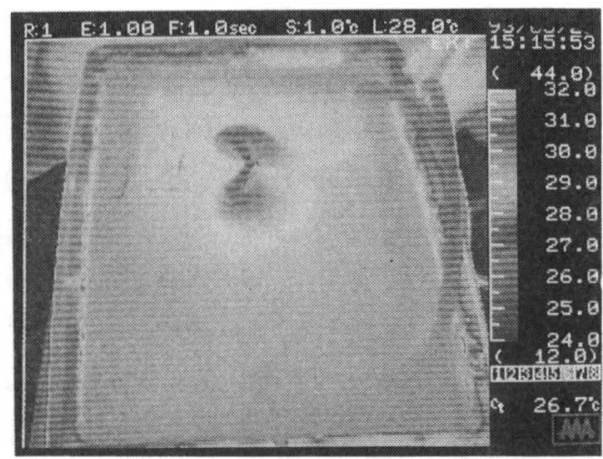

After 120 second

(b) $10 \mathrm{~cm}^{3} / \mathrm{min}$, Wall temp. $30^{\circ} \mathrm{C}$, Water temp. $25^{\circ} \mathrm{C}$

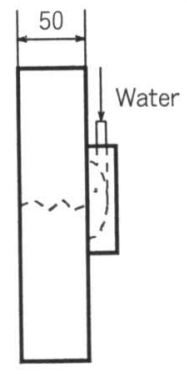

定できだ。

Fig. 12(a)拉よび Fig. 12(b) は, 試験体A 扩よ びBの表面の写真で, 試験体表面に放射温度画像 から確認できた亀裂の位置 $\mathrm{a} \sim \mathrm{g}$ を書き入れてあ る。試験体 $\mathrm{A}$ の写真(a)では, 試験体中央に比較的

Fig. 9 Test piece for an application 
大きな亀裂が確認できるが，放射温度画像による とこの亀裂からは漏洩していないことが分かる。 これに対して, 放射温度画像で確認できた漏洩箇 所に, 亀裂を目視できない箇所, 例党ば a や e な ど，が数箇所あった。これは, 試験体 Bについて あ同様のことが言える。例えば，bなど。

\section{4 土中漏洩箇所の検知}

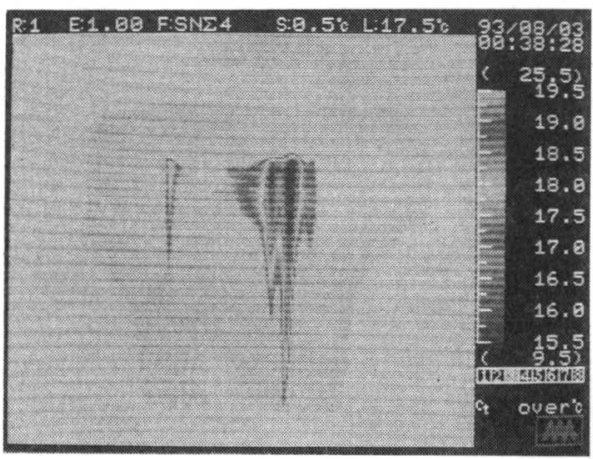

(a) $30 \mathrm{~cm}^{3} / \mathrm{min}$

Fig. 10 Thermograph on a mortar surface of test piece A

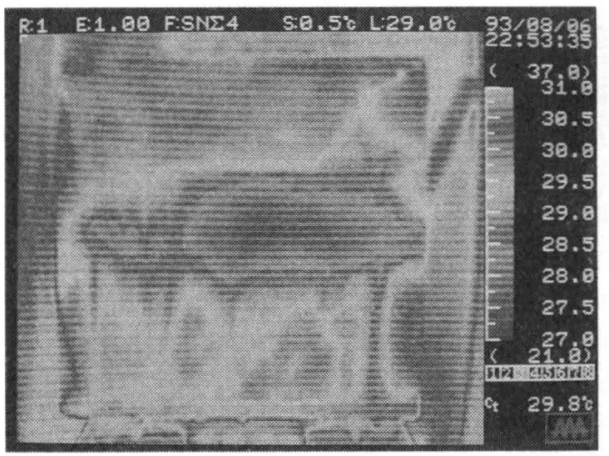

(a) $30 \mathrm{~cm}^{3} / \mathrm{min}$

Fig. 11 Thermograph on a mortar surface of test piece $B$

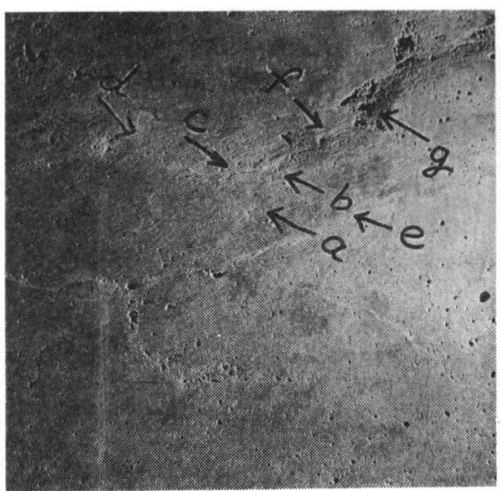

(a) Test piece of $\mathrm{A}$

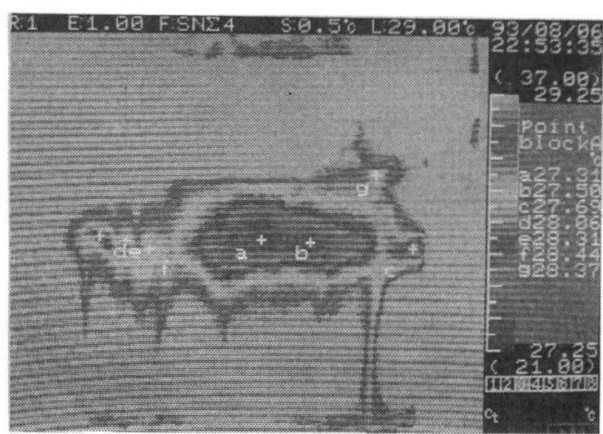

(b) $30 \mathrm{~cm}^{3} / \mathrm{min}$
一般に地下水の涌水は, 建築構造物壁面のみか らではなく，地層中から表面に漏洩する場合もあ る。したがって本研究では, 土中からの湧水箇所 の検出に赤外線映像装置を利用した実験も併せて 行った。

Fig. 13 (a)掠よび(b)は，砂の中に漏洩パイプを 埋めて, 湧水の広がる様子を赤外線映像装置で可

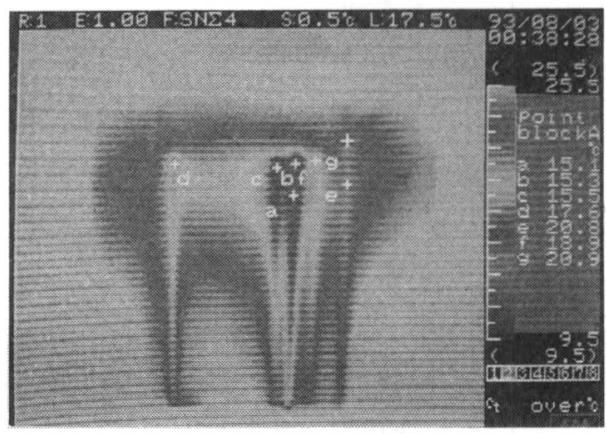

(b) $30 \mathrm{~cm}^{3} / \mathrm{min}$ 


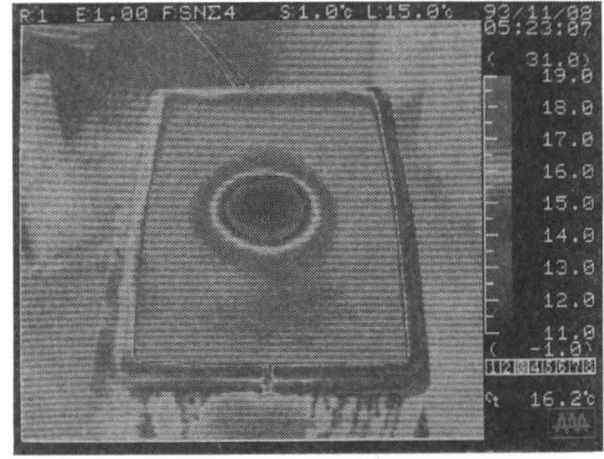

(a) $5 \mathrm{~mm}$ below

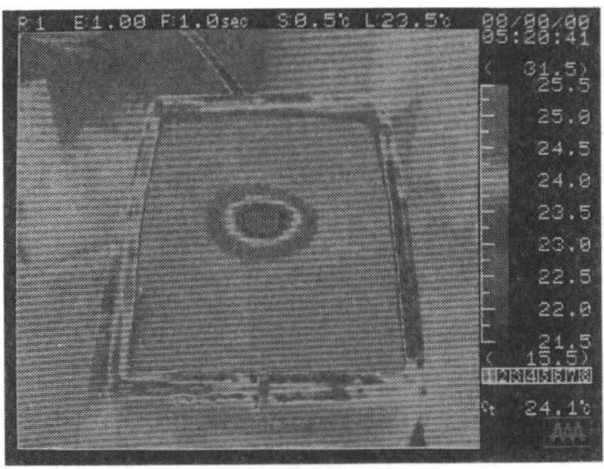

(b) $10 \mathrm{~mm}$ below

Fig. 13 Thermograph on a sand surface

視化した放射温度画像である。(a)と(b)はとれぞれ 砂の表面から $5 \mathrm{~mm}$ 打よび $10 \mathrm{~mm}$ 下に漏洩孔 を設置したものであり，漏洩流量はともに 10 $\mathrm{cm}^{3} / \mathrm{min}$ である。写真から分かるように漏洩水 は，漏洩䇢所を中心に，ほぼ円形に広がってお り，漏洩孔の位置が浅いほど，広がり方は大きく なっている。

\section{4. 結 論}

本研究は, 漏洩箇所検出に赤外線映像装置を適 用することで，その適用性扣よび有効性を検証し たものである。ここでは，堤防壁面の涌き水やコ ンクリート地下壁からの湧水など，涌き出乙箇所 が直接目視では特定できないような対象を取り上 げ，赤外線映像装置で可視化し，漏洩水の温度分 布を調べた。その結果, 本手法は漏洩箇所を特定 する上で有効な手段であることが明らかになっ た。また，壁面と漏洩水との温度差が $2^{\circ} \mathrm{C}$ 以下 の場合，漏洩箇所とその周辺の温度差が曖昧にな り，漏洩箇所を周辺を含めた範囲として検知する ことしかできない。この場合, 漏洩箇所周辺に温 水や冷水をかけて一時的に壁面と漏洩水との温度 差を大きくし, 漏洩筋の経時変化を可視化するこ とにより，漏洩箇所を点として検知することが可 能であることがわかった。また実際の亀裂面や土 中漏洩に関寸る実験から，亀裂の有無を目視でき ない箇所でも赤外線映像装置を利用することで, 漏洩筒所の検知が可能であることが明らかになっ
た。

本検出法は, 機器構造物の保守・管理だけでな く, 交通・輸送手段の安全性を確保する上で有効 な手段となるものと考えられる。

\section{記号表}

$A$ : 試験体上の濡れ面積, $C_{p}:$ 比熱, $d:$ 漏洩口 径, $L$ : 代表長さ (試験体全長), $m$ : 体積流量, $T_{0}$ : 漏油水入口温度, $T_{W}$ : 壁面温 度, $T_{X}$ : 漏 洩孔からの距離 $X \mathrm{~mm}$ に打訂る漏洩水温度, $U_{d}:$ 漏洩速度, $X:$ 漏洩孔からの垂直方向の距 離, $\zeta: \frac{X}{L} \cdot \frac{1}{R e}$ で定義される無次元 距離, $\theta: \frac{\left(T_{X}-T_{0}\right)}{\left(T_{W}-T_{0}\right)}$ で定義される無次元温度, $\lambda:$ 熱 伝導率, $\rho:$ 密度, $N u: \frac{\frac{\rho C_{p}\left(T_{W}-T_{0}\right) m}{A\left(T_{X}-T_{0}\right)} \cdot L}{\lambda}$ で 定義される無次元熱伝達率, $R e: \frac{U_{d} \cdot d}{\nu}($ レイ) ルズ数)

\section{参 考 文 献}

1）岡本他：赤外線による射度係数の測定と艺の応用，日本機 械学会論文集，B編，57，534，（3.1992）

2) 岡本他：赤外線による材料放射特性について，日本機械学 会論文集，B編，57，544，(12.1991)

3）岡本他：赤外線サーモグラフィー法によるモルタル試料表 面の放射温度画像, 日本コンクリート協会, サーモグラフ ィー法に関するコンファレンス論文集，409，(4.1992） 


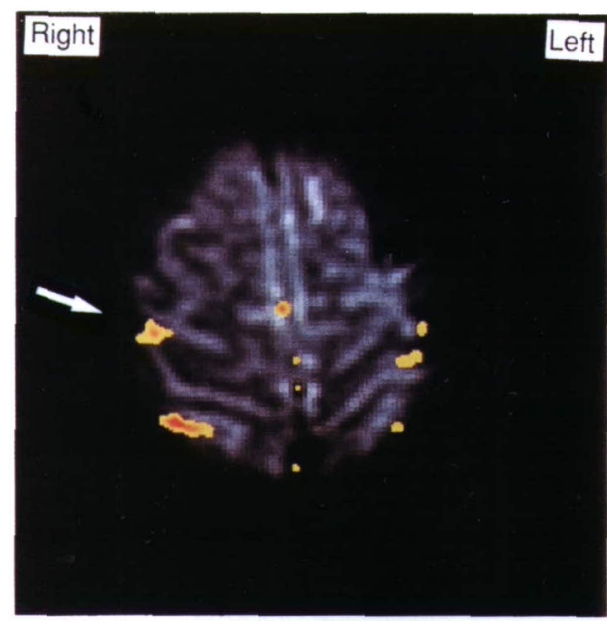

(a)左手の運動時

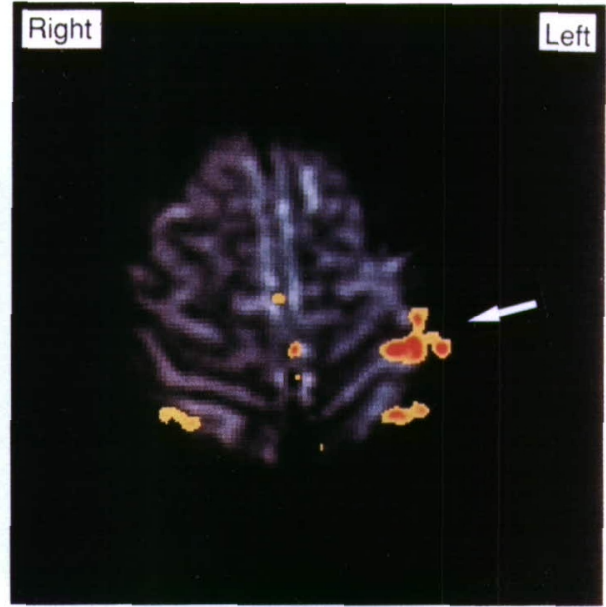

(b) 右手の運動時

口絵 5 超高速MR撮像法による運動野の賦活イメージング

(侏東芝研究開発センター 久原重英)(本文 229 頁参照)

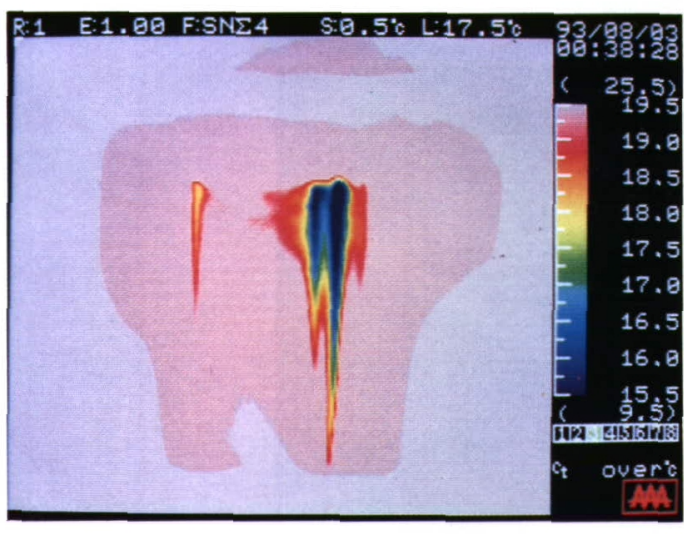

(a) $30 \mathrm{~cm}^{3} / \mathrm{min}$

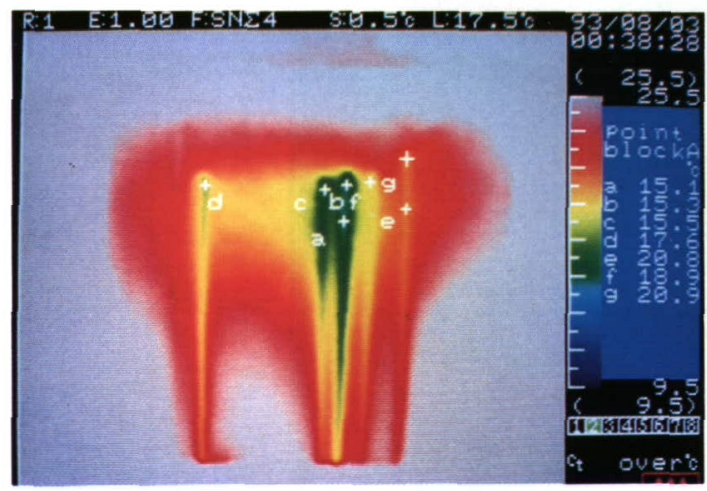

(b) $30 \mathrm{~cm}^{3} / \mathrm{min}$

口絵 6 Thermograph on a mortar surface of test piece $A$

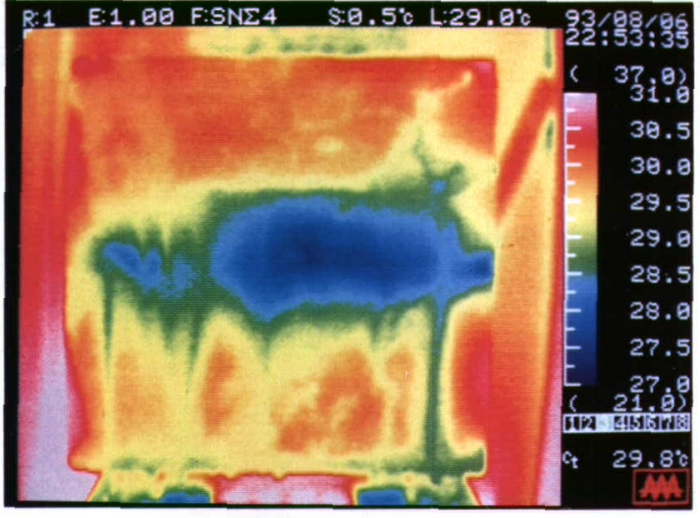

(a) $30 \mathrm{~cm}^{3} / \mathrm{min}$

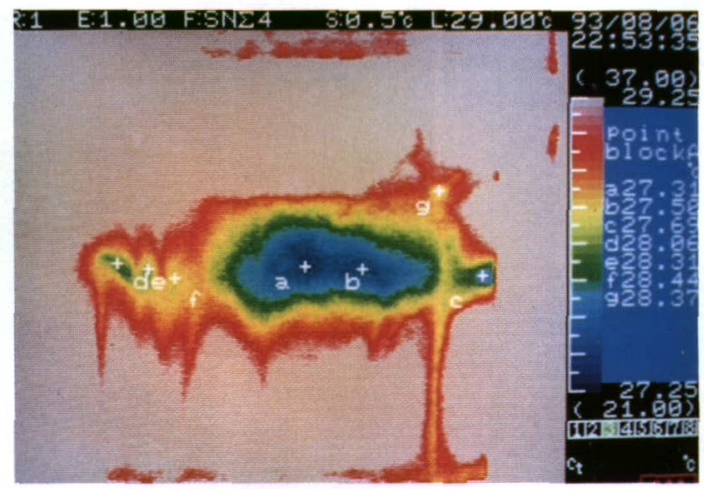

(b) $30 \mathrm{~cm}^{3} / \mathrm{min}$

口絵 7 Thermograph on a mortar surface of test piece $B$

(茨城大学 稲垣照美, 中村弘史, 岡本芳三)(本文235頁参照) 